\title{
"Doping Shadow Still Hard to Escape": Facing up to Reflections in German Print Media on Doping Scandal
}

\author{
Aleksandr Pastukhov* \\ Orel State Institute of Culture, Department Foreign Languages, 15, ul. Leskova, Orel, 302020 Russia
}

\begin{abstract}
The paper reflects important features and developments of doping affair with Russian sportsmen as a media scandal. This communicative event is introduced through the current examples taken from the German national and regional press. The mechanisms of the formation and topicalization of the event are revealed in the paper. The global context of the scandal is covered and exampled by co-referential areas "Sport" and "Olympics". Their presentation and interpretation occur under conditions of so-called "fake news" and "media performance" strategies. The examples presented in chronological order reflect the communicative dynamics of the media event "doping scandal'. The remarkable features of the distinguishing journalistic style and informative media genres are covered in the paper.
\end{abstract}

\section{Introduction}

The "suppliers" of collective knowledge, or intermediaries in its dissemination, are mass communication and mass media that never remain indifferent to what is mediated. The information about the world is actualized in communication in strict sequences, which are conventionalized in many ways, turning into so called "rules for constructing communicative units of a certain type". Having appeared firstly on the technological ways of fixing, broadcasting, preserving and replicating information, the mass media turned very soon into a powerful means of influencing mass consciousness.

Actually human perception is constantly influenced by modern media, thus this is the mode that reveals its impact in all spheres of life. This task, which is important in practical terms, concerns the description of psychological and discursive virtual models, when the global comprehension of media discourse semiotics and the particular media genres is still being carried out. As a rule, the traditions of a communicative-functional paradigm are reflected through the intra-system of language and cognitive mechanisms of any text (discourse) [1].

Targeting the media and journalism in research perspective we see that many topics are presented as brand news, what was no case before. The exiting 'media crisis' is not only a circle of special reporting during a time period. That might be hardly different, but already more than three decades ago there were media discussions about the alleged links in print and digital. At that time the journalist problems, dwindling confidence in the validity of reporting, in the quality of mass communication or in the ethical standards were mainly focus of attention. The emerging 'media' do not orient in the media space (not even because of the phenomenon of 'filter bubbles'), but are, at the same time, 'echo chambers', which is completely new. We know that print media, TV, the Internet with hundreds of channels make everyone be confined in the popular media in the content net of what they like or dislike.

Until today it is not clear where this journey will take us: especially in the situation of economic dislocations that cause disturbance. The efforts being a part of the audience (when it comes to the 'media' topic), have almost made the journalists the 'rioters'. Democratically elected politicians also use media resources, so the journalists become closer to the dictatorships and bursting topics of higher informational interest. Let us try to reconstruct and analyze one of them in the following paper.

\section{How mass media work today and what they do with us}

As we know, mass media are grounded on a basic contradiction, on the so called built-in 'schizophrenia' of the social institutions. The population and communication interests are focused on permanent information retrieval and exchange that are frequently contacted with the state affairs and living democracy. On the other hand, the institutions themselves are an industry and serve - in the broadest sense - to the economic or individual interests, as well as to the creation of the common values: enlightenment, freedom, maturity, reason etc.

Knowledge obligates mass media and their actors to be always on their pragmatic "side": the most significant goals: range, competition, deadlines, professionalism,

* Corresponding author: alexander.pastukhov@yandex.ru 
career-orientation reflect the conflicts between expectations of media and information services, in which media and journalists mutually are capable to face up the astonishing factors of the $21^{\text {th }}$ century. However, they basically act as a idealistic illusion, because the production and distribution of news is not a business after all, but the altruistic act. News waves may distract the mass media and the public. Some killer or leader issues may distract or attract attention towards victim or follower issues. So it is assumed that key events and corresponding news waves induce and drive issue relationship processes [2].

People are involved in, and in this process open communication, democratic publicity, cultural exchange, criticism and control, orientation and values become an important markers of it.

The reality of journalism refers also to the epistemologically or professionally meant question, with which exciting references of journalist activity in the worldview are presented. Particularly, when talking, writing and reporting about media and media institutions, persons etc. we usually get informed in considerable facts of common or specialized reality and the times that are in their turn notably influenced by the media. It could be also understood as 'foreign observation', when exclusively the journalistic means pretend to be something extraordinary, which does not belong to the illusion that is working on it. There are also proven methods that can revolve around the postulate of 'objectivity' [3]. These self-observation as an observation of a real world becomes increasingly risky. The next factor is the specially provided information marked by the downright passionate rejection of professional journalism and practices related to them.

\section{Themeing and Topicalization}

The journalism traditionally plays its role and takes care of topical themeing on some social orders of functional systems that requires an exclusive competence, exercised according to its own rules. In other words, we have to follow "how the world reflects the texts of mass media", "how the texts correlate with reality" and "what types of text are more suitable for describing reality".

We also have concern in "what kind of reality is created by the mass media texts", "what in the text makes us see a certain reality" and "how the text itself becomes reality" [4]. For example, the judiciary is exclusively concerned with legal issues and usually blinds everything. The science acts in opposite only through scientific questions due to the themeing. The media have a big open ability to influence that we call the social agenda.

The traditional and modern views in the discussion of the concept topic are associated with linguistic models of the thematic development that seems to be a central concept of discourse [5]. Topicalization refers to the sentence-initial placement of constituents other than the subject and is often listed as a non-canonical construction of "information packaging". It is assumed only to come to the fore in further developed varieties and after prolonged contact [6].

At the same time, the mentioned text variety can not be recognized as hypertext. In comparison with hypertexts, the discussed text bunch has more rigid principles of organization and is traced both in content and structural grounds. Moreover, thematically identified and simultaneously related sets of media texts have a unique cognitive basis - the structure of the media event that is reported by media texts form the corresponding set [7]. The aspired composition of media text is routinely based on the proceeding and selection of procedures that reflect events and set them into the form of messages. To find out the principally oriented 'news factors' and put them together by the relevant research is rather complicate task. At the center of this novelty the determining values are belonging to the conflict or center of the reader's attention. There are also proximity and prominent persons that are important ingredients of the 'human touch' in media too. So the news overall, which is characterized by economic, organizational and technical conditions, is based not on an emphatic concept of truth. The recent studies definitely show that news production, especially in electronic media, is strongly influenced by the process of actual themeing and becomes a starting point and subject of reader's orientation.

Does the news become more apolitical? In this obvious role it hardly attracts attention, but currently raises the 'Media Society' performed by the news players of media market [8]. Now media criticism indicates essentially the reflections and consequences of common market mechanisms. Mass media is not a verdict, in which inferior content logic is settled. It is strongly based on the contradiction, on the purpose to make more and more money, to prove standards for overbooked journalism. This growth may make new important settings to the roles of the media market.

\section{Problem Overview}

The concept of a 'world society' that indicates that the 'world media system' or even 'world journalism' are integrated into the 'World Society', i.e. they are purposed to permanent observation through globally active instructed media [9]. The empirical evidence in the time when news streams are constantly flowing in all directions and all corners of the Earth is networked through technical communication, for example, in the local news coverage. 'Operated' by agencies, many correspondents in the world serve to cheap journalism for information or expensive business that can be a "victory of economy over the claim". Normatively it is not so easy to state, because the press freedom, its legal design and ethical regulations are contingent worldwide. Accordingly the audience will be restricted by consumers and journalists in its role as entertainers. The commercialization of media - because of their influence in the advertising industry is equilibrating in the boundaries between facts and fictions, but this distinctive fact is not "'natural', therefore it must be coupled with the recipient's requirements. The author is doubted under 
conditions of 'Commercial Culture' due to the ethical standards, which may still be left to media actors alone. In particular, it is logically to follow the discrepancies of the permanent external media criticism [10]. Therefore I ask: is the perception of media - our perception, is their curiosity - the curiosity of the audience? The readers want to know how the author contributes to the reporting. Clearly different we notice it at the German journalists. After all, in the obituaries of media it would not have been appreciated that the entire media text is nothing else as a petty-bourgeois bashing. And if it so, it often resonates in the texts with a bit of contempt" [11].

\section{Real vs. Fake News and Media Performance}

Two trends have come to dominate in the social discourse: truthiness (validity of something based on how it feels) and post-fact (taking a position that ignores facts). Human discourse has always contained elements of these levels. So the complicated relationship has to find the implications for the intellectual and instrumental roots of the post-truth world [12].

Acceptance and perception of the so-called "Truth" in journalism, as we know, is closely related to the prospects of forms of expression. Truth seems extra required for the understanding of the real context of events. Therefore, the media as never before feel the needs for credibility and are deeply forced to constantly engaging and constructing of new worlds, in which even unnecessary information can be presented as plausible, and / or appear seemingly beneficial [13].

Apparently these and other media affairs are contributed to another technique of lost credibility for wide audiences. More people always have distrusted or hated journalists since the $1990 \mathrm{~s}$, even more than in decades before. Numerous surveys went further in their clearness that half of the reporting is often inaccurate or even mistaken [14]. At that time, leading German journalists in their question "What is Journalism for?" answer that 'Excellence in Journalism' is alone in the decline of the profession and such tendency can not be stopped yet.

In the view of more and more commercial goals of reverential media groups, different strategies are to be thrown out. Many reporters as possible want at this time to focus on coverage of low-price items, i.e. celebrities, court hearings, aircraft crashes, crime or firefighting. Declines and collapses of journalism as public service are very apparent in every facet of media. Various print media in Germany in the recent years have proven their clear evidence for these observations. In this reason print public services in Germany are always threatened with being sacrificed on the commercialization altar.

The loss of confidence in media coverage has become a constant point. If the 'media are an enemy of the people', so we can speak and declare the facts in the words of what was great in the German thinking for a long time. Confidence in the addressee's fake news is mostly contribute (for this or other reason) to the lack of verification in the purpose to fix the authenticity of the news or finding the apparently believable nature of the reported text [15].

The study of agenda-setting power of fake news and factcheckers who fight them at the mediascape dedicates that the fake content is increasing in the press. Instead, fake news has an intricately entwined relationship with the responding agenda setting. Emerging news media are also responsive to the agendas of fake news, but to a lesser degree. Fake news coverage itself is diverging and becoming more autonomous [16].

There after we think that informational provocations are characteristically situated in publications of facts, opinions, judgments, hypotheses, versions what is very plausible in nature, but not based on real information, etc. It is also clear that provocation becomes an act, but does not even necessarily lead to retaliatory actions. A distinctive feature of the informational provocation is the excitement in the media space. But the community is ready for a wide discussion that can generate diverse feed-back: opinion collapse, replicas, publications, comments and other known and accepted formats of statements, judgments in public discourse.

So the role of printed media in the maintenance of the so called stigmatization in media practice has been a subject of debate for several years. As for stigmatization of doping scandal, previous researchers have focused on stereotypes in newspaper articles and the metaphoric use of the doping scandal as something contradictory, aloof or ridiculous [17].

\section{Case Analyses. Reporting on Doping Scandal in German-Language Print Media}

Der Leichtathletik-Weltverband bleibt im russischen DopingSkandal kompromisslos. Am Sonntag hat das IAAF-Council in Monte Carlo entschieden, die Suspendierung des nationalen Verbandes RUSAF nicht aufzuheben. Ausschlaggebend für die Verlängerung des Russland-Banns war, dass die Welt-Anti-Doping-Agentur vor gut einer Woche die Suspendierung der russischen KontrollEinrichtung Rusada nicht aufgehoben hat (Frankfurter Allgemeine Zeitung. 26.11.2017).

The "Tagesschau" has informed on November 27, 2017 that the WADA has suspended the Russian anti-doping agency RUSADA. As a result, Russian athletes have again to hand over their medals: IOC imposed lifelong Olympic bans on five winter athletes. Thus, the results of 19 Russians at the Winter Games 2014 have been canceled:

In der vorigen Woche war auch der zweimalige BobOlympiasieger Alexander Subkow, zugleich Präsident des russischen Bobverbandes, auf Lebenszeit von Olympischen Spielen ausgeschlossen worden. ... Damit hat das IOC bereits für 19 russische Athleten in fünf Sportarten (Bob, Skeleton, Skilanglauf, Eisschnelllauf und Biathlon) lebenslange Sperren verhängt und deren Resultate von den Winterspielen 2014 annulliert (Tagesschau. 27.11.2017).

From the scandal chronicle of November 2017, we knew also:

5. November 2017: Die "New York Times" schreibt, das IOC erwäge unter anderem ein Verbot der russischen Hymne bei den Winterspielen in Pyeongchang und einen Ausschluss russischer Athleten von der Eröffnungsfeier. 
10. November 2017: Die Wada hat möglicherweise das entscheidende Puzzleteil für den Nachweis eines staatlich gelenkten Dopingsystems in Russland erhalten. Die Wada teilt mit, dass das hauseigene Ermittlerteam in Besitz des LIMS des Moskauer Dopinglabors gelangt sei.

16. November 2017: Die Wada entscheidet sich gegen eine Wiederaufnahme der Rusada. Noch immer verweigert Russland eine öffentliche Anerkennung der Berichte Richard McLarens.

24. November 2017: Das IOC sperrt auch den russischen Volkshelden Alexander Subkow lebenslang für Olympia. Der Bobpilot, der in Sotschi die Fahne bei der Eröffnungsfeier trug und jetzt Präsident des nationalen Verbandes ist, gewann in Sotschi zweimal Gold (Der Spiegel. 05.12.2017).

In the "Neues Deutschland" in the correspondence »Von sauberen Spielen sollte keiner reden «, journalist Oliver Kern criticizes the Russia, the IOC, and the leadership of the World Anti-Doping Agency:

... ich würde lügen, wenn ich sage, dass ich es nich bemerkenswert finde, dass wir so viel ausgelöst haben. ... Ich bin Journalist, ein Berichterstatter, kein Staatsanwalt. ... wir beobachten Dinge im Sport, die wir nicht gut finden, weil sie nicht korrekt sind oder mit dem übereinstimmen, was Leute erzählen ... (Neues Deutschland. 23.12.2017).

Due to the doping scandal, Russia's athletes are only allowed to participate in the 2018 Olympic Winter Games in Pyeongchang under a neutral flag. This was decided by the Executive of the International Olympic Committee at its meeting in Lausanne. At the same time, the IOC has ruled out the National Olympic Committee of Russia (ROC) because of the doping scandal during the Winter Games. Also the former Minister of Sport and current Deputy Prime Minister Witali Mutko was locked for life for Olympic Games:

Der umstrittene russische Sportfunktionär Witali Mutko hat viele Posten. Er steckt nach IOC-Ermittlungen tief im russischen Doping-Sumpf. Nun zieht er eine Konsequenz - mit überschaubaren Folgen. Als Organisator der Fußball-WM erscheint er unverzichtbar. Mutko ist ein langjähriger sportpolitischer Weggefährte von Präsident Wladimir Putin. Den Fußballverband führte er von 2005 bis 2009 und ließ sich 2015 erneut an die Spitze wählen. Das Internationale Olympische Komitee (IOC) hält den Sportminister Mutko für einen der Verantwortlichen im russischen Doping-Skandal. Das IOC hat Mutko Anfang Dezember lebenslang für Olympia gesperrt. ... Die russische Politik weist den Vorwurf systematischen Dopings zurück und spricht von Einzelfällen (Die Hannoversche Allgemeine Zeitung. 25.12.2017). Only three days before the opening ceremony of the Winter Games, 32 Russian athletes are still fighting for their participation. The group around the Olympic champion Viktor Ahn and Anton Shipulin pull with complaints before the Swiss Federal Court and the International Court of Justice (CAS):

Unabhängiges Komitee entscheidet: Welche russischen Athleten dürfen bei den Winterspielen starten? ... Doping ist kein neues Thema - insbesondere in Russland. Am Montag startet eine Anhörung von 42 russischen Sportlern, die wegen Dopings vom IOC lebenslang gesperrt wurden. Dann soll sich entscheiden, ob die Athleten an den Olympischen Winterspielen in der südkoreanischen Stadt Pyeongchang teilnehmen dürfen. (Schleswig-Holsteinische Zeitung. 22.01.2018)

The Russian team has been also excluded from the Winter Paralympics in Pyeongchang, but it was allowed for individual athletes to start under a neutral flag:

Ausgewählte russische Behindertensportler dürfen unter neutraler Flagge an den Paralympics in Pyeongchang (9. bis 18. März) teilnehmen. Wie das Internationale Paralympische Komitee (IPC) am Montag in Bonn bekannt gab, bleibt das Russische Paralympische Komitee (RPC) zwar aufgrund des staatlich gelenkten Dopingsystems in Russland suspendiert (Frankfurter Rundschau. 29.01.2018).

In the ARD-documentary, the key witness Grigory Rodchenkov directly accused Vladimir Putin of being aware of state doping in Russia: The Russian President Vladimir Putin said on 9 November 2017 that the US accuses of using the doping scandal to discredit the Russian government: "In response to our alleged disruption to their elections, they want now to cause problems in our presidential champagne. At the press conference in January 2018 in Sochi Vladimir Putin said that:

Was Rodtschenkow, zentrale Figur des Doping-Systems in seinem Land, wiederholt sei ,nicht glaubwürdig“. ... Das Internationale Olympische Komitee (IOC) hat auch auf Grundlage von

Rodtschenkows Aussagen das Nationale Olympische Komitee Russlands gesperrt. Es lässt aber 169 individuell geprüfte Athleten des Landes bei den Winterspielen im Februar - ohne Hymne,

Fahne und eigene Kleidung an den Start gehen (Süddeutsche Zeitung. 29.01.2018).

In the ZEIT-Interview "Dass Putin vom Staatsdoping wusste, überrascht nur Herrn Hoene $\beta$ " asks the physician Fritz Sörgel on the latest doping revelations: Dopen only the Russians? Can you leave tests now? Will the main witness be murdered soon?

ZEIT ONLINE: Man könnte, gut eine Woche vor Beginn der Olympischen Winterspiele, den Eindruck gewinnen, im Sport wird alles immer schlimmer. Oder wissen wir heute bloß mehr?

Sörgel: Es ist in der Tat so, dass wir heute einfach mehr wissen. Das ist in vielen anderen Bereichen des gesellschaftlichen Lebens nicht anders. Im Sport aber besonders, weil die Aufmerksamkeit für Sportskandale größer ist als noch vor Jahrzehnten.

ZEIT ONLINE: Jetzt, wo man weiß, dass selbst Journalisten Dopingproben manipulieren können - kann man Dopingtests sein lassen?

Sörgel: Nein. Das würde ja bedeuten, dass man dann kapituliert, wenn etwas nicht funktioniert. Wie in der Technik muss man die Tests und die Nachweisverfahren im Antidopingkampf immer weiter entwickeln (Die Zeit. 31.01.2018).

"No mercy for Viktor Ahn, Anton Shipulin and Co.: Russia's biggest Sports Stars are excluded from the Winter Olympics calls the headline in the "Die Zeit": Olympia-Aus für Russland-Stars. CAS: Prozedere rechtmäßig.

Der Internationale Sportgerichtshof CAS wies die Klage von 45 weiteren russischen Sportlern und zwei Betreuern wenige Stunden vor der Eröffnungsfeier zurück und erklärte das umstrittene Einladungs-Prozedere des Internationalen Olympischen Komitees (IOC) für rechtmäßig. Schon am Vortag hatte die Ad-hocKommission des CAS bei 13 russischen Athleten und Offiziellen ein ähnliches Gesuch abgelehnt und sich als nicht zuständig erklär (Die Zeit. 09.02.2018).

The doping case of the Russian curlers Alexander Kruschelnitsky was officially caused by the doping chamber of the International Court of Sport (CAS). It confirmed that Kruschelnizki had also been tested in Pyeongchang in the B sample positive for the banned heart drug Meldonium. The CAS excluded him from the Games.

Ob das Curling-Team der "Olympischen Athleten aus Russland" die Bronzemedaille, die Kruschelnizki gemeinsam mit seiner Ehefrau Anastassija Brysgalowa im Mixed-Wettbewerb gewonnen hat, zurückgeben muss, steht noch nicht fest (Focus. 22.02.2018). At the Winter Games in Pyeongchang, there was another positive doping test in the team "Olympic Athletes from Russia". This was confirmed by the Russian Bob Association. Accordingly to this, the pilot Nadeshda 
Sergeyeva was tested positive on 18 February for a banned heart remedy.

„Der Test der Bob-Pilotin der russischen Nationalmannschaft ergab ein positives Ergebnis auf ein Herzmittel, das auf der Liste der verbotenen Substanzen enthalten ist”. „Ein paar Tage davor, am 13. Februar, war ihr Test sauber. ... Der Bob-Verband Russlands und die Athletin selbst sind sich des Ausmaßes ihrer Verantwortung und der Auswirkungen des Vorfalls auf das Schicksal des gesamten Teams bewusst" (Bild. 23.02.2018).

On 24 February the IOC decides timely before the end of the Winter Games about a possible readmission of the Russians to the closing ceremony under its own flag. The renewed doping case will be another burden for the meeting of the IOC executive.

Am zweiten russischen Dopingfall in Pyeongchang gibt es keine Zweifel mehr. Der Sportgerichtshof CAS bestätigte die Diqualifikation von Bobpilotin Nadeschda Sergejewa. Sie muss das Olympische Dorf verlassen.

Die russische Bobpilotin Nadeschda Sergejewa ist bei den Olympischen Winterspielen des Dopings überführt worden. Die 30-Jährige verzichtete auf die Öffnung ihrer B-Probe, gab ihre Akkreditierung zurück und hat das Olympische Dorf verlassen. Die Ad-hoc-Kammer des Internationalen Sportgerichtshofs Cas bestätigte den Vorfall (Der Spiegel. 24.02.2018).

\section{Doping Scandal Bottles: New Revelations Come out}

The reports about sports obviously cheat in many nations today. The journalists are responsible for the news representation. But they have more properly to listen and read their contributions too. They would at least know how to classify those discrepant messages. Many of the eye-catching doping news could not be convicted in the years 2015 to 2018. At that time the anti-doping fighters had neither the necessary analytical methods nor the legal handle. As we know, the biological passport, via which athletes can be condemned according to conspicuous blood values.

Even if doping fighters were very likely to know scammers in those years, they could not get hold of them. Thus, the journalistic and discursive research of the sport media on doping should not be alleviated. But the messages remain terrifying. A more serious reception and processing of their work are actually desired. The markers of conflict are imprinted in textual forms of verbalization and accentuation of the discourse. The important markers of the conflict are imbedded into the headers, which are due to the specific position and functional significance of the text composition.

Primarily media scandals were formed as "discourses that are designed by journalists and in which non-public actions, processes and situations of social value, norms or moral codes are presented" [18]. In addition to this, media scandals can differ by number of publications, length of the text, professionally vs. unprofessional statements etc. In other words the active promotion of a mediated scandal is firstly associated with the professional design of the scandal [19].

As already mentioned, the media content is often incorrectly displayed and no day goes by without doping news. This has less to do with the fact than with the fraud cases that happen during the Olympic Games. For never before headlines can be sold to cheating athletes better around a major event. As we know, the scandal generates big audiences. If we have a closer look at the key messages on the doping by the Russian athletes in German press around the years 2017 to 2018, so we can see that statements about abnormalities in the blood values can be made beyond those persons. If in this time (2005 to 2018) the suspected athletes have brought medals, so they automatically were counted to the «involved» persons.

Kein Tag vergeht zurzeit ohne Dopingnews. Das hat weniger damit zu tun, dass sich die Betrugsfälle alle gerade zum jetzigen Zeitpunkt ereignen würden als mit den bevorstehenden Olympischen Spielen. Denn nie lassen sich Schlagzeilen um betrügende Athleten besser verkaufen als rund um einen Großanlass. Er generiert nämlich erst die grosse Einschaltquote. ... Damit soll die Recherche von Hajo Seppelt, dem bekanntesten Doping-Rechercheur, keineswegs gemindert werden (Der Tagesanzeiger. 04.02.2018).

\section{Conclusion}

It is well known that the viability of a form is associated with its temporary transience. For media communication - as well as for the concepts of system and evolution the choice of rationality is not predetermined. Relating to this elementary level, we see that the forms are less constant than the medial substrate [20]. According to diverse sports reporting, Russian politicians and spokesmen protested heavily at the content of the messages they have to read on the topic. All Russians were deeply touched by the mentioned false news. It was reported on the not disclosed criteria of journalistic writing and rated the messages as 'fake news'. We can not classify such communicative behavior in the newspapers as "exotic," because it is in the traditional standards that exist in western media systems.

Consider this, we can say that the modern journalism and 'true' statements about sports reflect from various perspectives and achievements, but rather often they are specifically evaluated and bring to the disappointment, even anger as a report that is perceived by the audience as 'distorted'. They all seem to be on a high level of 'truth' that explains why the debate so emotionally is conducted. Following this extra linguistic and culturalspecific scenario, it is possible to determine how the feelings to the extent or situation are determined by expression of physical, visual and verbal reactions on the social adequacy, authenticity and truth. Thus feelings and emotions come under the collective cultural consciousness, which are encoded in a system of social obligations conventionalized in the codes of feelings expression [21].

But on the other side the epistemology of constructivism categorically propagates that the absolute standards such as 'Truth' and 'Objectivity' are set on a wrong track [22]. The means of journalism and the reality of the constructivist logic can be reconciled with the empirical findings on human perception and communication. Biologists, psychologists, brain researchers, cyberneticians find new points out to bring to the readers something new, to help them by their orientation and direct access of the 'world' picture - arguing over the 
needs of 'reality' abandons as a remarkable reference instance [23].

Today, more than ever, the very important mater is not the reality. More important are the principles that are followed in this situation. Media entertainment formats are mostly printed or recorded under 'live conditions'. Anyone who has been involved into the audience for reading or watching is fully integrated into the process of media staging while reader or spectator is animated with enthusiasm, even when time-delayed facts are broadcasted or printed as News. Even the 'objectivity' demands from the journalist a very relative scale. It is oriented on pragmatic criteria, when the objectivity is mostly described as a 'strategic ritual' that fits the routines and business practices of the media. If we go a step further in this approach, so we see that the journalists are only observers, who do not report about things, properties or relationships in World-InThemselves, but about the results. This also has very important consequences for the understanding of real objectivity.

\section{References}

1. A.G. Pastukhov, Hypertext as an Object of Linguistic Research (Samara, 2010)

2. S. Geiß, Int. Journal of Public Opinion Research 23(3), 265-286 (2011)

3. G. Tuchman, American Journal of Sociology 4(77), 660-679 (1971-72)

4. E.A. Kozhemyakin, T.R. Krasikova, Media Linguistics 1(11), 31-40 (2016)

5. A.G. Pastukhov, Discourse of Modern Mass Media (Belgorod, Constanta, 2014)

6. S. Leuckert, Zeitschrift für Anglistik und Amerikanistik 65(3), 283-302 (2017)

7. L.I. Grishaeva, Bulletin of Voronezh State University. Linguistics and Intercultural Communication 3, 60-63 (2017)

8. G. Ruhrmann, R. Göbel, Veränderung der Nachrichtenfaktoren und Auswirkungen auf die journalistische Praxis in Deutschland (Wiesbaden, 2007)

9. P. Sloterdijk, "Technologie und Weltmanagement" (Medien-Zeit, Stuttgart,1994)

10. L. Bogart, Commercial Culture (New York, Oxford, 1995)

11. S. Christ, Medienkritik: Warum sich Journalisten und Leser immer schlechter verstehen (Huffington Post, 2.5.2014)

12. P.R. Berthon, F.L. Pitt, Journal of Macromarketing 38(2), 218-227 (2018)

13. A.G. Pastukhov, Scientific Bulletins of the Belgorod State University 2(209), 26, 102-112 (2015)

14. B. Kovach, T. Rosenstiel, The Elements of Journalism: What News People Should Know and the Public Should Expect (New York, 2007)
15. N.N. Panchenko, Theoretical and Applied Aspects of the Study of Speech Activity. Nizhny Novgorod State Linguistic University 1, 164-169 (2013)

16. C.L. Vargo, L. Guo, M.A. Amazeen, New Media \& Society 20(5), 2028-2049 (2018)

17. B. Schlier, \& T. Lincoln, Psychotherapeut 59, $293-$ 299 (2014)

18. S. Burkhardt, Medienskandale. Zur moralischen Sprengkraft öffentlicher Diskurse (Köln, 2006)

19. I.A. Ushanova, Vestnik of the Novgorod State University 73(1), 129-132 (2013)

20. A.G. Pastukhov, Genres and Text Types in the Scientific and Media Discourse 6, 272-281 (2008)

21. A.G. Pastukhov, Genres and Text Types in the Scientific and Media Discourse 11, 159-174 (2013)

22. E. V. Glasersfeld, Das Auge des Betrachters (München, 1991)

23. R. Nüse et al., Über die Erfindung/en des Radikalen Konstruktivismus (Weinheim, 1991) 